Hydrology and Earth System Sciences, 6(3), 299-313 (2002) C C EGS

\title{
The prediction and management of aquatic nitrogen pollution across Europe: an introduction to the Integrated Nitrogen in European Catchments project (INCA)
}

\author{
A.J. Wade, P.G. Whitehead and L.C.M. O'Shea \\ Aquatic Environments Research Centre, Department of Geography, University of Reading, Reading, RG6 6AB, UK \\ Email for corresponding author: andrew.wade4@btinternet.com
}

\begin{abstract}
Excess nitrogen in soils, fresh water, estuarine and marine systems contributes to nutrient enrichment in key ecosystems throughout Europe, often leading to detrimental environmental impacts, such as soil acidification or the eutrophication of water bodies. The Integrated Nitrogen model for European Catchments (INCA) project aims to develop a generic version of the Integrated Nitrogen in Catchments (INCA) model to simulate the retention and transport of nitrogen within river systems, thereby providing a tool to aid the understanding of nitrogen dynamics and for river-basin management/policy-making. To facilitate the development of the model, 10 partners have tested the INCA model with data collected in study sites located in eight European countries as part of the INCA project. This paper summarises the key nitrogen issues within Europe, describes the main aims and methodology of the INCA project, and sets the project in the context of the current major research initiatives at a European level.
\end{abstract}

Keywords: Europe, European Union, nitrogen, nitrate, ammonium, river basin management, modelling, water chemistry, acidification, eutrophication, Water Framework Directive, INCA.

\section{Introduction}

Across the European Union (EU) there are concerns about nitrogen $(\mathrm{N})$ in lowland and upland fresh water systems, estuaries and marine areas. In such systems, if $\mathrm{N}$ is the limiting nutrient, additional $\mathrm{N}$ inputs can cause rapid aquatic plant growth, leading to eutrophication. The problems of eutrophication are usually associated with lowland, intensively farmed areas where fertilisers provide a significant source of $\mathrm{N}$ or urban areas where domestic and industrial effluent is discharged to the receiving watercourse and groundwaters. However, increasing $\mathrm{N}$ deposition from the atmosphere has led to increased problems in the uplands. For example, increased atmospheric deposition of $\mathrm{N}$ leads to soil and streamwater acidification (Skeffington and Wilson, 1988; Hornung et al., 1994, 1995). $\mathrm{N}$ inputs also alter plant diversity and enhance eutrophication of upland streams and lakes. In addition, there is evidence that many of Europe's forests are N saturated, leaching $\mathrm{N}$ in excess of plant and microbial demand (Emmett et al., 1995; Wilson and Emmett, 1997). Thus, $\mathrm{N}$ inputs to river systems have a significant impact on groundwaters and the aquatic environment, often with consequences downstream, thereby influencing options for water utilisation and affecting the ecosystem health of estuarine and marine areas, which are often $\mathrm{N}$ limited.

European management strategies have tended to address single issues (e.g. diffuse or point sources) or particular regions (e.g. upland or lowland areas). However, it is recognised that the $\mathrm{N}$ status of river systems reflects the combined contribution of sources: fertiliser inputs, atmospheric deposition and sewage discharges. Superimposed on these anthropogenic inputs are contributions from the vegetation and mineralisation and nitrification of organic $\mathrm{N}$ in soils. Thus, given the holistic nature of the $\mathrm{N}$ problem, an integrated management approach is required (Langan et al., 1997). In particular, such an approach is needed to assess the likely impacts of land management, $\mathrm{N}$ deposition and climatic change on $\mathrm{EU}$ river $\mathrm{N}$ concentrations and loads. The importance of this is acknowledged in the United States of America where an 
integrated approach is being implemented through permit trading between diffuse and point source polluters (EPA, 1999).

Developing such integrated management strategies for the control of $\mathrm{N}$ in river water is a complex task. The regulation of $\mathrm{N}$ inputs to catchments is difficult due to inadequate information relating to the abatement costs, the identification of the polluters in the case of diffuse pollution, the damage to the ecosystem caused by excess $\mathrm{N}$ concentrations and the pollution production function. The function relates the catchment $\mathrm{N}$ input to the output and is affected by the complex $\mathrm{N}$ dynamics in the plant/soil system and in the stream, by climatic and seasonal factors (e.g. soil wetness, temperature) and by land use and management practice: afforestation, clear-felling, liming, ploughing and grazing. In addition, given the numerous contributors to the $\mathrm{N}$ load in the river, regulation is likely to involve and affect a wide range of activities such as agriculture, transport and power generation.

The development of an integrated approach for assessing chemical transport in river catchments has been the focus of the Land Ocean Interaction Study (LOIS, Wilkinson et al., 1997). The conclusions drawn from this work highlight the need to understand hydrochemical process interactions and to develop appropriate catchment water quality models (Neal et al., 1997, 1998). Models are useful as they formalise ideas regarding the factors and processes controlling water chemistry (Wheater and Beck, 1995). Moreover, they provide initial estimates of the likely impacts of environmental change on water chemistry (Jenkins et al., 1997).

INCA is a recently developed model that links hydrological behaviour, the microbiological processes controlling $\mathrm{N}$ transformation and multiple sources of $\mathrm{N}$ inputs to catchments (Whitehead et al., 1998a, b; Wade et al., 2002). The aims of this paper are to describe (a) the INCA project and the INCA model, and (b) how the work planned as part of the INCA project will address key water quality and modelling issues.

\section{INCA project objectives}

The INCA project aims to apply the model across Europe to investigate the $\mathrm{N}$ dynamics of key ecosystems. By replicating the application of INCA to a wide range of ecosystems and river catchments, the model will be tested and developed as a tool for assessing the $\mathrm{N}$ dynamics in both the plant/soil system and in river networks. For the individual ecosystems, the work will predict the changes, in the streamwater $\mathrm{N}$ concentrations and loads, likely to result from changes in land management, pollutant inputs and the climate. The results will be used to infer the likely impacts at the pan European scale. Furthermore, the role of the economic component is to determine how different institutional frameworks, comprising elements such as taxation, best management practice and Common Agricultural Policy (CAP) reform, will affect water quality. To achieve this, a new economic model will be developed to assess the changes in agricultural practice in response to these elements. The resultant changes in agricultural practice will be used as inputs to INCA, to determine the streamwater $\mathrm{N}$ concentration response in European rivers.

The specific objectives of the project are as follows:

1. to establish hydrological and water quality databases for a range of key European ecosystems;

2. to apply the process-based dynamic model, INCA, to these selected catchments across Europe;

3. to establish $\mathrm{N}$ budgets in the catchments and compute fluxes of $\mathrm{N}$ on a daily, seasonal and annual basis both for the plant/soil system and in stream;

4. to modify the model process equations as necessary to develop a generic model applicable to a wide range of ecosystems and catchments;

5. to use the model to assess the impacts of land management, atmospheric deposition and climatic change in the catchments selected;

6. to compute fluxes of nitrous oxide gas release from catchments, riparian zones, wetlands and stream beds;

7. to investigate model parameter and structural uncertainty and scale-up from the plot to the large (c. $4000 \mathrm{~km}^{2}$ ) catchment scale;

8. to add an economic component to the INCA project to assess the costs of a range of $\mathrm{N}$ controls in agriculturally intensive catchments within Europe;

9. to create an easy to use Windows version of INCA with high quality graphics for management and scientific use;

10. to make INCA available to the European Environment Agency, National Environment Agencies, the Water Industry and other interested parties.

The project began in April 1999 and contributes to the EU's environment programme, Key Action 1.1.4 Sustainable Management and Quality of Water, specifically research priority 1.1.1, Strategic planning and integrated management methodologies and tools at the catchment scale. The project objectives address issues that are central to the programme: ecosystem functioning and the development of catchment management tools. The creation of hydrological and water quality databases will permit assessments to be made of the key $\mathrm{N}$ source and sink processes in ecosystems throughout Europe (objective 1). The application of INCA to the 
different ecosystems using the data will simulate the concentrations and fluxes in the streams and rivers, and provide initial quantitative estimates of the $\mathrm{N}$ fluxes associated with the $\mathrm{N}$ processes in the plant/soil systems (objectives 2 and 3). The development of a generic version of INCA, applicable to all the different ecosystems studied will provide a useful management tool (objective 4), which can be used to assess the impacts of land management, $\mathrm{N}$ deposition and climatic change on riverine $\mathrm{N}$ concentrations and loads, and $\mathrm{N}$ dynamics in plant/soil system (objective 5). The model will also be developed to estimate nitrous oxide gas fluxes (objective 6), contributing to Key Action 2 "Global Change, Climate and Biodiversity". Parameter uncertainty will be investigated by comparing the parameter sets generated from the model applications to determine those parameters with the greatest influence on the model output. In addition, the model results will be compared with those from other models to corroborate the predictions. INCA is based on mass-balance and as such it can be applied across a range of spatial scales. Thus it will be used to investigate scale-up (objective 7) through comparison of $\mathrm{N}$ flux estimates made at the plot scale with those made at the catchment scale. The economic contribution will build upon the information and results obtained from the INCA model by utilising the information regarding the key characteristics determining the flow of $\mathrm{N}$ within a catchment area. The economic model will be used subsequently to investigate the effects of different control instruments for regulating $\mathrm{N}$ pollution (objective 8). The conclusions from the work will be widely disseminated, with the model being made available to end-users (objectives 9 and 10).

\section{General setting}

Europe covers approximately $7 \%$ of the land surface of the Earth, though the geographical boundaries that constitute Europe are ill defined, particularly where Europe abuts Asia. The continent contains a complex range of geological environments, soil cover, climatic zones and land-use types. Scandinavia and northern and western UK are dominated by Precambrian rock, which though resistant to weathering is base-poor, and therefore the thin overlying soils are sensitive to acidification. The vegetation in these mountainous areas tends to be dominated by coniferous forest, grasses or barren areas on exposed or high altitude outcrops. Thin mountain soils are also found in the principal Cenozoic folded areas of the Alps, Pyrenees and Apennine Mountains. From the Benelux countries in the east to northern Germany and Poland in the west, the rocks are mainly Cenozoic sedimentary rocks overlaid by podzolic soils of temperate climes. Podzolic soils are also the most abundant in central France and England where the climate is also temperate, though the underlying rocks are mainly Paleozoic and Mesozoic sedimentary. In central Spain, areas of Chernozemic soils of a semi-arid climate support mainly grasslands.

At present, the EU comprises 15 member countries and together these cover an area of 3.2 million $\mathrm{km}^{2}$. Humans have had a significant impact on the EU landscape; hardly any area of Europe can be considered as in a natural/pristine condition. Even isolated mountain areas have been affected by atmospheric deposition. The natural climax vegetation across Europe would be woodland, and indeed the largest land use is forestry, which covers an area of approximately 1 million $\mathrm{km}^{2}$. This figure includes both natural and seminatural woodland, much of it in marginal areas especially in Scandinavia as well as extensive areas of commercial forestry where the climate and the terrain limit the scope for animal husbandry. Together, the forested areas of Austria, Finland Sweden, France, Germany, Italy and Spain account for nearly $90 \%$ of EU forests. The areas of member states influenced climatically by the Atlantic, such as western France, Germany, Spain, Ireland and western UK, are mainly wet and temperate and, therefore, show more emphasis on grass production. The majority of arable land within the EU is found in France, Germany, Italy, Spain and the UK, which in combination accounts for approximately $75 \%$ of the EU total arable area (Van de Velde et al., 1994).

Stanners and Bordeau (1995) published the Dobris Assessment, which summarised the state of the European environment, including a description of river water quality; they reported that dissolved inorganic $\mathrm{N}$, particularly nitrate $\left(\mathrm{NO}_{3}\right)$ and ammonium $\left(\mathrm{NH}_{4}\right)$, constitutes approximately $88 \%$ of the total dissolved $\mathrm{N}$ in river water and, therefore, is generally the form focused upon in scientific studies. In addition, within Europe, $\mathrm{NO}_{3}$ concentrations are generally lowest in rivers in Norway, Sweden and Finland, where the median $\mathrm{NO}_{3}$ concentration is only $0.18 \mathrm{mg} \mathrm{N}^{-1}$. In Western Europe, the median $\mathrm{NO}_{3}$ concentration is around $3.5 \mathrm{mg}$

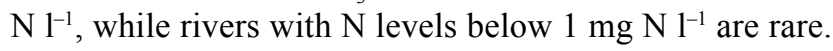
$\mathrm{N}$ levels exceeding $1 \mathrm{mg} \mathrm{N}^{-1}$ indicate an anthropogenic influence, for example agricultural runoff or sewage effluent. Moreover, $\mathrm{NO}_{3}$ concentrations increased between 1977-82 and 1988-90 in more than two thirds of European rivers, the median concentration increase being $0.14 \mathrm{mg} \mathrm{N} \mathrm{1}^{-1}$, or $13 \%$. This increase was most marked in Eastern and Southern European rivers, because of the significant increase in the use of $\mathrm{N}$ fertilisers during the same period. However, in many Western European countries, the increase in the use of $\mathrm{N}$ fertilisers peaked in the late 1970s and remained at that high level during the 1980 s. For $\mathrm{NH}_{4}$, concentrations in $70 \%$ of 230 river systems mainly in western European 
and Nordic countries decreased over the same periods. This decrease probably reflected improved wastewater treatment and the consequent reduction in organic matter discharge. $\mathrm{NO}_{3}$ leaching to groundwater depends primarily on the time and rate of application, crop uptake, the soil type and climatological conditions. In Europe, there is a lack of $\mathrm{NO}_{3}$ monitoring data for groundwater, though groundwater contamination with $\mathrm{NO}_{3}$ is recognised as a problem.

Atmospheric deposition of acidifying substances over Europe has decreased since about 1985, due in part to the implementation of the United Nations Economic Commission for Europe's (UN/ECE) 1994 Oslo Protocol on Further Reduction of Sulphur Emissions and also to a slow down in industrial growth due to economic recession. Total $\mathrm{N}$ emissions in Europe (nitrogen oxides plus ammonia), which remained roughly constant between 1980 and 1990, fell by about $15 \%$ between 1990 and 1995 due mainly to the Central and Eastern European states and Newly Independent States (NIS) which experienced a significant down-turn in industrial productivity. However, concerns over the impacts of $\mathrm{N}$ derived from atmospheric deposition and agriculture remain a major concern regarding European (and World) ecosystem health (COM (99) 125).

\section{INCA model}

In the last few years, there has been a considerable amount of activity in the field of $\mathrm{N}$ modelling. Many of the recently developed N models, such as MAGIC-WAND (Cosby et al., 1985a, b: Jenkins et al., 1996), MERLIN (Cosby, et al., 1997), PNET-CN (Postek et al., 1995) and others (e.g. Thornley and Cannell, 1992) are directed towards upland ecosystems, forests or particular processes. Other processbased models have been developed for lowland agricultural systems to assess the impacts of fertiliser application on soils, ground- and surface waters (e.g. Addiscott and Whitmore, 1987; Cooper et al., 1993). These tend to be dynamic models that can provide short-term (weekly) information. Some models such as QUASAR (Whitehead et al., 1997; Whitehead and Williams, 1984) address $\mathrm{N}$ dynamics in rivers specifically, accounting for in-stream processes such as nitrification and denitrification. Despite all these developments, there are still very few models that integrate catchment and river processes. A recent model by Lunn (1995) addresses the whole catchment in a distributed manner but is driven by a complex hydrological model, SHE (Système Hydrologic Européen) (Abbott et al., 1986). The export coefficient method of Johnes (1996) is more pragmatic; it models $\mathrm{N}$ dynamics empirically, based on observations and historical records of land use. This technique has proved very successful for estimating annual and seasonal $\mathrm{N}$ loads. However, the model is not processbased and cannot be used to generate daily variations in river $\mathrm{N}$ concentrations. Furthermore, very few studies have linked model output to economics. Some exceptions include Vatn et al. (1997), Johnson et al. (1991) and Weaver et al. (1996). These differ in their modelling approaches and it will be interesting to compare results with those generated from the INCA project.

To aid the understanding of river system $\mathrm{N}$ dynamics, there is clearly a need for catchment $\mathrm{N}$ models which track $\mathrm{N}$ inputs from the atmosphere and fertiliser through catchment soils to the river, and address the spatial variation across the catchment (e.g. land use, vegetation, hydrology) which influences $\mathrm{NO}_{3}$ levels down the river profile. INCA has been developed to bring all these elements together in a single model: INCA is

- dynamic - so that river and soil-water $\mathrm{NO}_{3}$ and $\mathrm{NH}_{4}$ concentrations and fluxes are produced as a daily time series, incorporating temporal variation in hydrological flow paths and $\mathrm{N}$ transformations in both catchment and river;

- stochastic - so that parameter sensitivity can be assessed and outputs derived in probabilistic or percentile terms;

- semi-distributed - so that the spatial variations in land use and management, effluent discharges and $\mathrm{N}$ deposition can be taken into account. (The term semidistributed is used here, as it is not intended to model catchment land surface in a detailed manner. Rather, different land use classes and sub-catchment boundaries are modelled simultaneously and information fed sequentially into a multi-reach river model.)

There are five components to the model:

1. A GIS interface that defines sub-catchment boundaries and calculates the areas of different land use types in each sub-catchment.

2. A N input model that calculates the total $\mathrm{N}$ inputs from all sources to each sub-catchment, scaling dry deposition and fertiliser application according to land use.

3. A hydrological model which simulates the flow of effective rainfall in the reactive and groundwater zones of the catchment and within the river itself. This component of the model drives the $\mathrm{N}$ fluxes through the catchment.

4. A catchment $\mathrm{N}$ process model that simulates $\mathrm{N}$ transformations in the soil and groundwater of the catchment.

5. A river $\mathrm{N}$ process model that simulates dilution and inriver transformations and losses. Net $\mathrm{N}$ output from each sub-catchment (component 4) provides the $\mathrm{N}$ flux into 
the corresponding river reach and input to the river $\mathrm{N}$ process model.

A full description of the original model, which includes the equations used to simulate the $\mathrm{N}$ dynamics in the plant/ soil system and in the stream is given in Whitehead et al. (1998a) (Figs. 1 and 2). The land use hydrological model is essentially a daily mass balance such that daily water flows are computed for soil, groundwater and leaching to the river for up to six land uses. The river model makes use of conventional non-linear reservoir dynamics to route the water down the river system.

Whilst solving the flow equations, it is necessary to solve the mass balance equations for both $\mathrm{NO}_{3}-\mathrm{N}$ and $\mathrm{NH}_{4}-\mathrm{N}$ in both the soil and groundwater zones. The key processes that require modelling in the soil zone are plant uptake for $\mathrm{NH}_{4}$ and $\mathrm{NO}_{3}$, ammonia nitrification, denitrification of $\mathrm{NO}_{3}$, mineralization, immobilization and $\mathrm{N}$ fixation (Fig. 1). The process rates will vary from land use to land use. To capture this behaviour in the model, a generalised set of equations describes the processes and six parameter sets are derived, one for each of the different land uses. Further, the land phase model accounts for all the inputs affecting each land use including dry and wet deposition of $\mathrm{NH}_{4}$ and $\mathrm{NO}_{3}$ and fertiliser addition for both $\mathrm{NH}_{4}$ and $\mathrm{NO}_{3}$ (e.g. as ammonium nitrate). Air temperature and soil moisture data are input to the model, with the air temperature used in the calculation of the soil temperature. Within the model, the soil $\mathrm{N}$ processes are assumed to be temperature and soil moisture dependent. In the groundwater zone, it is assumed that no biochemical reactions occur and that a mass balance of $\mathrm{NH}_{4}$ and $\mathrm{NO}_{3}$ is adequate. In the river, the key processes are denitrification of $\mathrm{NO}_{3}$ and nitrification of $\mathrm{NH}_{4}$ (Fig. 2). The reach mass balance accounts for these two processes and incorporates the upstream $\mathrm{NO}_{3}$ and $\mathrm{NH}_{4}$ inputs together with inputs from the soil zone and groundwater zone in addition to direct effluent discharges. INCA has been applied to several U.K. river systems with promising results, though a need for further developmental work was noted (Whitehead et al., 1998b; Wade et al., 2001).

\section{Project description}

\section{THE INITIAL PHASES OF THE STUDY}

The initial phases of the study involved the identification of the suitable plot studies and river systems (which are summarised in Table 1) and the collation of the historic data into a format suitable for the INCA applications (Tables 2 to 4). Twenty-three study sites throughout Europe have been chosen as test cases for the application of the model. The sites encompass a broad range of climatic, geology, soil and

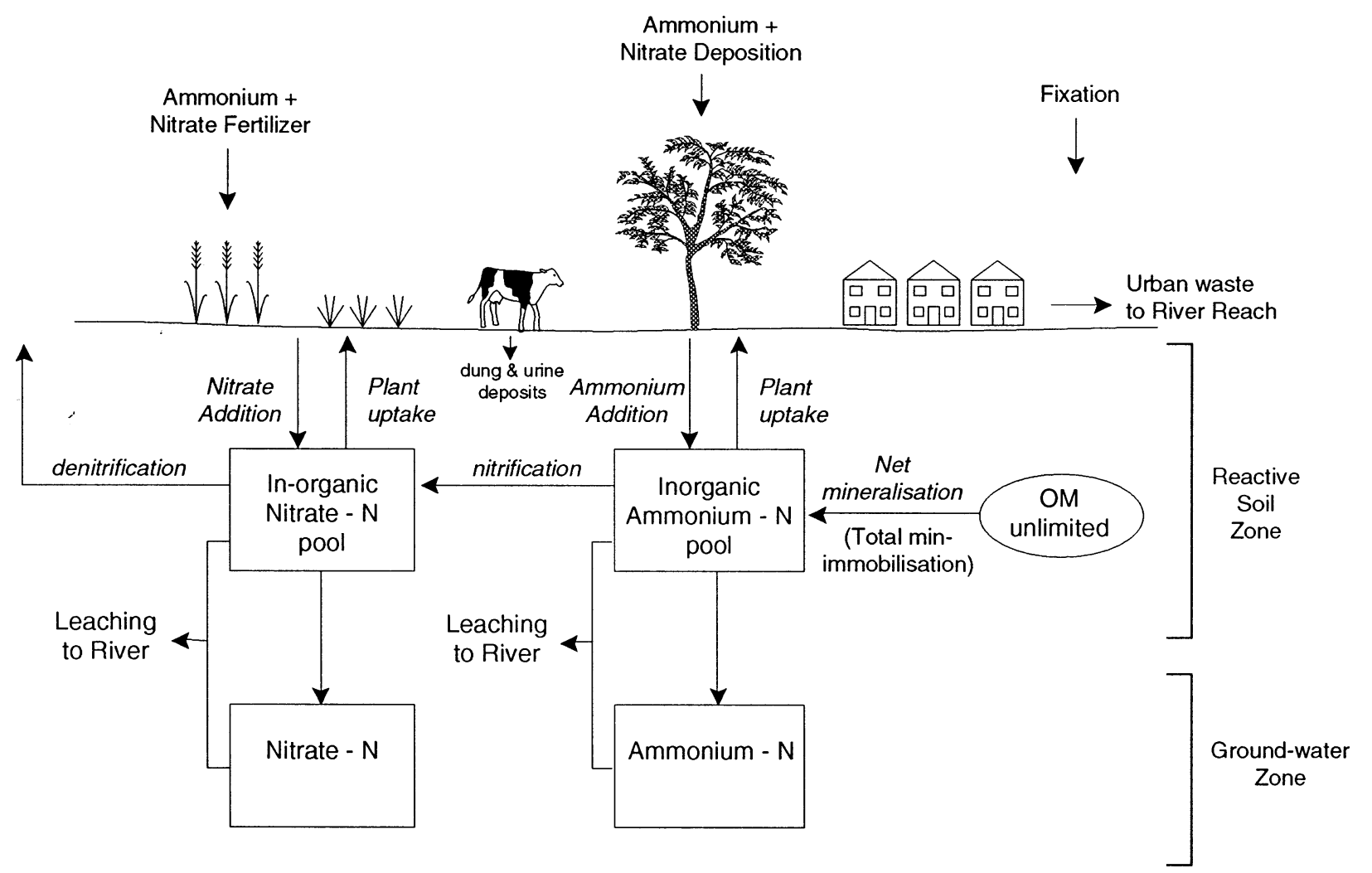

Fig. 1. $N$ plant/soil system processes included in the INCA model (After Whitehead et al., 1998a: published with permission of STOTEN, Elsevier). 
Instream processes

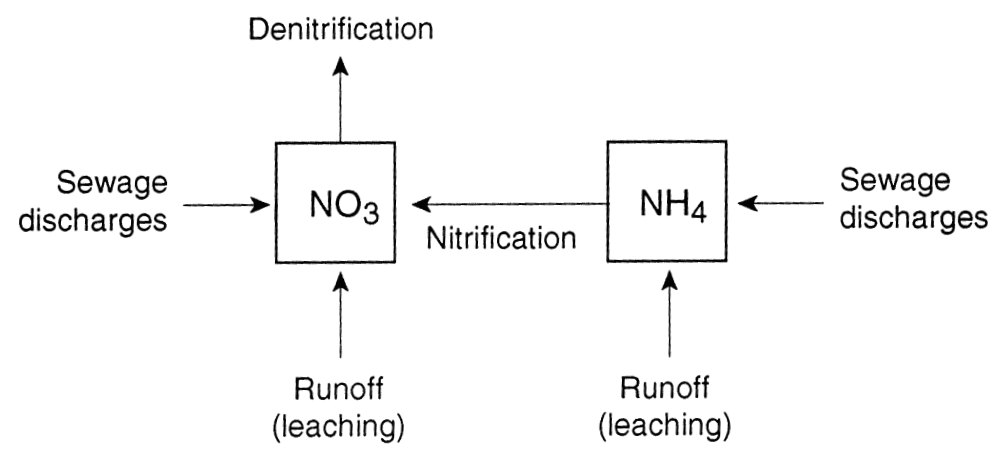

Multi-reach structure

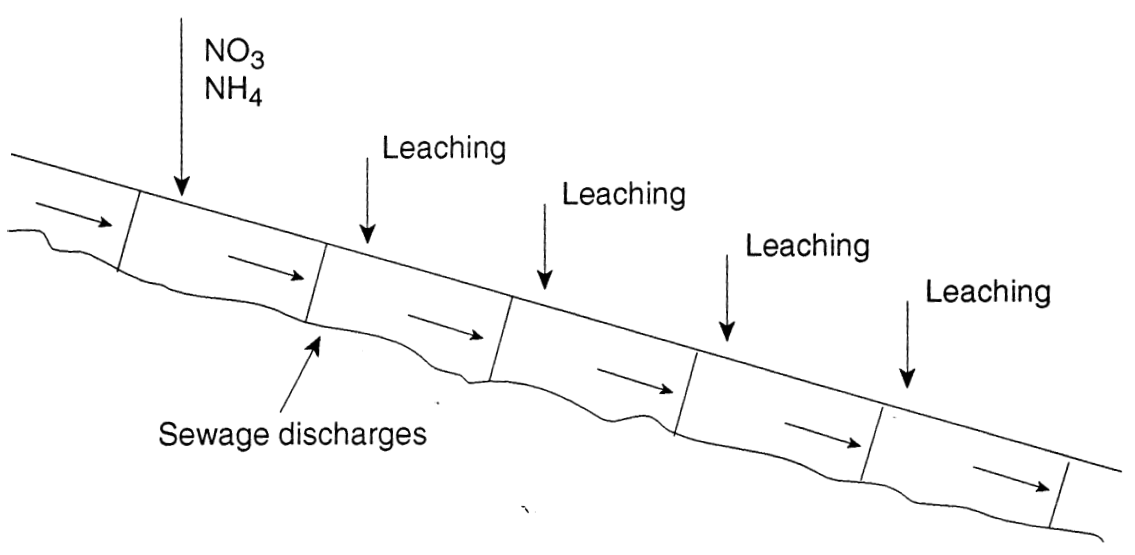

Fig. 2. Riverine $N$ processes and transformations included in the INCA model (After Whitehead et al., 1998a: published with permission of STOTEN, Elsevier).

land-use types, and range in spatial scale from plot studies to large river catchments of approximately $4000 \mathrm{~km}^{2}$. To ensure the range of study plots and catchments was suitable to meet the aims and objectives of the project, three criteria were stipulated: the study area had to

- be a significant regional resource, or part of a larger river system that formed a significant regional resource;

- be subject or sensitive to changes in one, or preferably more, sources of $\mathrm{N}$ pollution;

- have some background data with which the INCA model could be calibrated and tested and the $\mathrm{N}$ processes be examined.

The study sites are in Denmark, The Netherlands, Germany, Norway, Finland, Spain, France and the UK and their locations are shown in Fig. 3.

The areas of the study sites range over six orders of magnitude, from the plot studies in Oldebroekse heide, The Netherlands $\left(5000 \mathrm{~m}^{2}\right)$ to the River Tweed system on the border of Scotland and England $\left(4390 \mathrm{~km}^{2}\right)$. The salient features of the sites are as follows:

- Denmark, The Netherlands and Germany. There are 18 study plots in Vestskoven, Denmark, 6 study plots in Veluwe infiltration area (including the Edese bos itself) in The Netherlands, and two small catchments at Lehstenbach $\left(4.2 \mathrm{~km}^{2}\right)$ and Steinkreuz $\left(0.55 \mathrm{~km}^{2}\right)$ in Germany (Langusch and Matzner, 2002a, b). All these sites are forested, the Danish plots including a mix of coniferous and deciduous species, mainly Norway spruce and oak. The Dutch sites comprise a mixture of forest and heathland, and Norway spruce and European beech dominate the Lehstenbach and Steinkreuz catchments, respectively. The main issue at all these sites, is the sensitivity of the systems to changes in $\mathrm{N}$ deposition and likelihood of $\mathrm{N}$ leaching to the soil, stream and groundwaters. In addition, the Danish application aims to examine the changes in the soil and soilwater $\mathrm{N}$ loads following the planting of forest on formerly agricultural land, whilst application to the 
Table 1. A summary of the sites and data used in the INCA project. Acid. $=$ Acidification, Eutr $=$ Eutrophication and $\mathrm{N}$ sat. $=\mathrm{N}$ saturation.

\begin{tabular}{|c|c|c|c|c|c|}
\hline Country & $\begin{array}{l}\text { Sites/river } \\
\text { system }\end{array}$ & $\begin{array}{l}\text { Label in } \\
\text { Fig. } 3\end{array}$ & $\begin{array}{l}\text { Area } \\
\left(\mathrm{km}^{2}\right)\end{array}$ & Predominant land use & Major issue \\
\hline UK & $\begin{array}{l}\text { Leith Hill } \\
\text { Ant } \\
\text { Kennet } \\
\text { Tweed }\end{array}$ & $\begin{array}{l}1 \\
2 \\
3 \\
4\end{array}$ & $\begin{array}{l}0.93 \\
49.3 \\
1033 \\
4390\end{array}$ & $\begin{array}{l}\text { Forest and grassland } \\
\text { Arable } \\
\text { Arable } \\
\text { Improved pasture and arable }\end{array}$ & $\begin{array}{l}\text { Acid. } \\
\text { Eutr. } \\
\text { Eutr. } \\
\text { Eutr. }\end{array}$ \\
\hline FinLAND & Simojoki & 5 & 3160 & Coniferous Forest/Wetland & Acid. \\
\hline GERMANY & $\begin{array}{l}\text { Lehstenbach } \\
\text { Steinkreuz }\end{array}$ & $\begin{array}{l}6 \\
6\end{array}$ & $\begin{array}{l}4.19 \\
0.55\end{array}$ & $\begin{array}{l}\text { Coniferous Forest } \\
\text { Deciduous Forest }\end{array}$ & $\mathrm{N}$ sat. and Acid. \\
\hline FRANCE & $\begin{array}{l}\text { Kerbernez } \\
\text { Stang Cau } \\
\text { Pouliou } \\
\text { Kervidy } \\
\text { Stimoes } \\
\text { Pont-Veuzit }\end{array}$ & $\begin{array}{l}7 \\
7 \\
7 \\
7 \\
7 \\
7\end{array}$ & $\begin{array}{l}0.35 \\
0.86 \\
0.75 \\
4.9 \\
12 \\
59\end{array}$ & $\begin{array}{l}\text { Arable } \\
\text { Arable } \\
\text { Arable } \\
\text { Arable } \\
\text { Arable } \\
\text { Arable }\end{array}$ & $\begin{array}{l}\text { Eutr. } \\
\text { Eutr. } \\
\text { Eutr. } \\
\text { Eutr. } \\
\text { Eutr. } \\
\text { Eutr. }\end{array}$ \\
\hline $\begin{array}{l}\text { THE } \\
\text { NeTHERLANDS }\end{array}$ & $\begin{array}{l}\text { Buunderkamp } \\
\text { Leuvenum } \\
\text { Speuld } \\
\text { Kootwijk } \\
\text { Oldebroekse heide } \\
\text { Edese bos }\end{array}$ & $\begin{array}{c}8 \\
8 \\
8 \\
8 \\
8 \\
8\end{array}$ & $\begin{array}{l}0.04 \\
0.04 \\
0.16 \\
0.16 \\
0.005 \\
10\end{array}$ & $\begin{array}{l}\text { Oak forest } \\
\text { Douglas Fir forest } \\
\text { Douglas Fir forest } \\
\text { Douglas Fir forest } \\
\text { Heathland } \\
\text { Heathland }\end{array}$ & $\begin{array}{l}\text { N sat. and Acid. } \\
\text { N sat. and Acid. } \\
\text { N sat. and Acid. } \\
\text { N sat. and Acid. } \\
\text { Eutr. } \\
\text { N sat. and Eutr. }\end{array}$ \\
\hline NORWAY & $\begin{array}{l}\text { Bjerkreim } \\
\text { Dalelv }\end{array}$ & $\begin{array}{l}9 \\
10\end{array}$ & $\begin{array}{l}619 \\
3.2\end{array}$ & $\begin{array}{l}\text { Coniferous forest } \\
\text { Arctic tundra }\end{array}$ & $\mathrm{N}$ sat. and Acid. \\
\hline Spain & Fuirosos & 11 & 16.2 & Forest and arable & Eutr. and Acid. \\
\hline DenMark & $\begin{array}{l}\text { Vestskoven } \\
\text { (18 plots) }\end{array}$ & 12 & Variable & $\begin{array}{l}\text { Coniferous and deciduous } \\
\text { forest }\end{array}$ & $\mathrm{N}$ sat. \\
\hline
\end{tabular}

Edese bos $\left(10 \mathrm{~km}^{2}\right)$ infiltration area aims to assess the impact of $\mathrm{N}$ deposition on groundwater $\mathrm{N}$ concentrations in an area where the groundwater is used as a public water supply (Raat et al., 2002). During the last 15 years, $\mathrm{NO}_{3}$ concentrations in the recently infiltrated groundwater have risen, causing concern about the future groundwater quality.

- Norway. There are two catchment sites in Norway. The Dalelv catchment $\left(3.2 \mathrm{~km}^{2}\right)$ is located in the Norwegian Arctic and comprises tundra (Kaste and Skjelkvale, 2002). As such, the Dalelv represents the most pristine system in the INCA project, with low nutrient inputs. In contrast, the Bjerkreim river system in southern Norway is a larger catchment $\left(619 \mathrm{~km}^{2}\right)$, subjected to elevated $\mathrm{N}$ deposition. Applications of the INCA model to these systems will facilitate the study of the potential impacts of $\mathrm{N}$ deposition in areas thought to be the most sensitive to small changes in $\mathrm{N}$ deposition due to the relatively low streamwater $\mathrm{N}$ concentrations.

- Finland. The study site in Finland is the Simojoki system, a Northern Boreal river basin, which covers an area of $3160 \mathrm{~km}^{2}$ (Rankinen et al., 2002). The river system is dominated by coniferous forest and wetlands, where the major issues are $\mathrm{N}$ leaching from the forests and acidification by atmospheric $\mathrm{N}$ deposition. As such, INCA will be used to explore the impacts of land-use, $\mathrm{N}$ deposition and climate change on $\mathrm{N}$ processes in wetland-forest ecosystems, where the soils are frozen for approximately seven months and snow covered for five-six months of the year. 
Table 2. A summary of the catchment hydrological monitoring data used in the INCA project

\begin{tabular}{|c|c|c|c|c|c|c|c|}
\hline Gauge name & Watercourse & $\begin{array}{l}\text { Drainage } \\
\text { area } \\
\mathrm{km}^{2}\end{array}$ & Frequency & $\begin{array}{l}\text { Period of } \\
\text { collection }\end{array}$ & $\begin{array}{l}\text { Mean daily } \\
\text { flow } \\
m^{3} s^{-1}\end{array}$ & $\begin{array}{l}\text { Average } \\
\text { annual } \\
\text { runoff } \\
\mathrm{mm}\end{array}$ & $\begin{array}{l}\text { Average } \\
\text { annual } \\
\text { precipitation } \\
\mathrm{mm}\end{array}$ \\
\hline \multicolumn{8}{|l|}{ UK } \\
\hline Leith Hill & Tillingbourne & 0.93 & continuous & 1998- & & & \\
\hline Honing Lock & Ant & 49.3 & “ & 1966- & 0.31 & 200 & 645 \\
\hline Marlborough & Kennet & 142 & “ & 1972- & 0.83 & 185 & 795 \\
\hline Knighton & Kennet & 295 & “ & $1962-$ & 2.46 & 264 & 781 \\
\hline Newbury & Kennet & 548 & “ & 1990- & 4.48 & 258 & 767 \\
\hline Theale & Kennet & 1033 & “ & $1961-$ & 9.53 & 291 & 768 \\
\hline Kingledoors & Tweed & 139 & “ & 1961- & 5.4 & 1221 & 1634 \\
\hline Lyne Ford & Tweed & 373 & “ & $1961-$ & 10.5 & 886 & 1327 \\
\hline Boleside & Tweed & 1500 & “ & $1961-$ & 38.0 & 800 & 1227 \\
\hline Sprouston & Tweed & 3330 & “ & 1969- & 65.4 & 619 & 1038 \\
\hline Norham & Tweed & 4390 & “ & $1962-$ & 79.6 & 572 & 990 \\
\hline Ormiston Mill & Teviot & 1110 & “ & 1960- & 19.6 & 558 & 978 \\
\hline \multicolumn{8}{|l|}{ FINLAND } \\
\hline Simo, outlet 410 & Simojoki & 3160 & continuous & $1.1 .1965-$ & $37.2(1965-90)$ & 377 & 680 \\
\hline Hosionkoski 310 & Simojoki & 1981 & “ & $1.1 .1962-$ & $24.6(1962-90)$ & 392 & 700 \\
\hline \multicolumn{8}{|l|}{ GeRMANY } \\
\hline Lehstenbach & Lehstenbach & 4.19 & biweekly & 1993-99 & 0.0711 & 525 & \\
\hline Steinkreuz & Steinkreuz & 0.55 & biweekly & $1995-99$ & 0.0028 & 171 & \\
\hline \multicolumn{8}{|l|}{ France } \\
\hline Kerbernez & Odet & 0.35 & continuous & 11/97- & & & \\
\hline $\begin{array}{l}\text { Stang Cau } \\
\text { (Tremargat) }\end{array}$ & Blavet & 0.86 & “ & $1996-$ & 0.016 & & \\
\hline $\begin{array}{l}\text { Pouliou } \\
\text { (Tremargat) }\end{array}$ & Blavet & 0.75 & “ & 1996- & 0.015 & & \\
\hline Kervidy & Coet Dan & 4.9 & “ & $1992-$ & 0.06 & & \\
\hline Stimoes & Coet Dan & 12 & “ & 1971- & 0.11 & & \\
\hline Pont-Veuzit & Yar & 59 & “ & 1982- & 0.80 & & \\
\hline \multicolumn{8}{|l|}{ NORWAY } \\
\hline Maudal & Bjerkreim & 55.4 & continuous & 1993-95 & & 2798 & $3172^{1}$ \\
\hline Bjordal & “ & 123.4 & “ & “" & & 2735 & $3155^{1}$ \\
\hline Austrum & “ & 60.9 & “ & on-going & & 3013 & $3452^{1}$ \\
\hline Gjedla & “ & 618.5 & “ & “ & & 2530 & $2659^{1}$ \\
\hline Øygard & “ & 2.55 & “ & “ & & 1811 & $2140^{1}$ \\
\hline Høgmo & “ & 0.56 & “ & $1993-95$ & & 1651 & $2478^{1}$ \\
\hline Svela & “ & 0.51 & “ & “ & & 1393 & $2140^{1}$ \\
\hline Longa & “ & 0.83 & “ & “ & & 994 & $1549^{1}$ \\
\hline Outlet & Dalelv & 3.2 & continuous & 1989- & & 458 & $607^{2}$ \\
\hline \multicolumn{8}{|l|}{ SPAIN } \\
\hline$\# 3$ & Fuirosos & 16.2 & $\begin{array}{l}7-10 \text { days } \\
\text { (baseflow) } \\
1-2 \mathrm{hrs} \\
\text { (storms) }\end{array}$ & $\begin{array}{l}\text { From May } \\
1998\end{array}$ & 0.025 & 74 & 613 \\
\hline $\begin{array}{l}{ }^{1} 1993-1995 \\
{ }^{2} 1993-1999\end{array}$ & & & & & & & \\
\hline
\end{tabular}


Table 3. A summary of plot hydrological monitoring data used in the INCA project.

\begin{tabular}{|c|c|c|c|c|c|}
\hline Site name & $\begin{array}{l}\text { Drainage Area } \\
\mathrm{km}^{2}\end{array}$ & $\begin{array}{l}\text { Frequency of } \\
\text { collection }\end{array}$ & $\begin{array}{l}\text { Period of } \\
\text { collection }\end{array}$ & $\begin{array}{l}\text { Average Annual } \\
\text { Flow/Runoff } \\
\mathrm{mm}\end{array}$ & $\begin{array}{l}\text { Average Annual } \\
\text { Precipitation } \\
\mathrm{mm}\end{array}$ \\
\hline \multicolumn{6}{|l|}{ Germany } \\
\hline Steinkreuz Plot & 0.5 & biweekly & 1995-1999 & $238(1996-1998)$ & 731 (1996-1998) \\
\hline \multicolumn{6}{|l|}{ NetherLANDS } \\
\hline Buunderkamp & 0.04 & fortnightly & Oct.' 88 - Jul.'’91 & 317 & 843 \\
\hline Leuvenum & 0.04 & “ & Jul.' 89 - Jul.'91 & 154 & 800 \\
\hline Speuld & 0.16 & “ & Jan.' 88 - Jul.'91 & 156 & 800 \\
\hline Kootwijk & 0.16 & “ & Jan.'88 - Jul.'91 & - & 800 \\
\hline Oldebroekse heide & 0.005 & “ & Dec.'98 - present & - & 800 \\
\hline Edese bos & 10 & & present & & \\
\hline \multicolumn{6}{|l|}{ Denmark } \\
\hline $\begin{array}{l}\text { Vestskoven (18 plots, } \\
\text { one stream/ditch) }\end{array}$ & Variable & monthly & Dec.'98 - & - & 600 \\
\hline
\end{tabular}

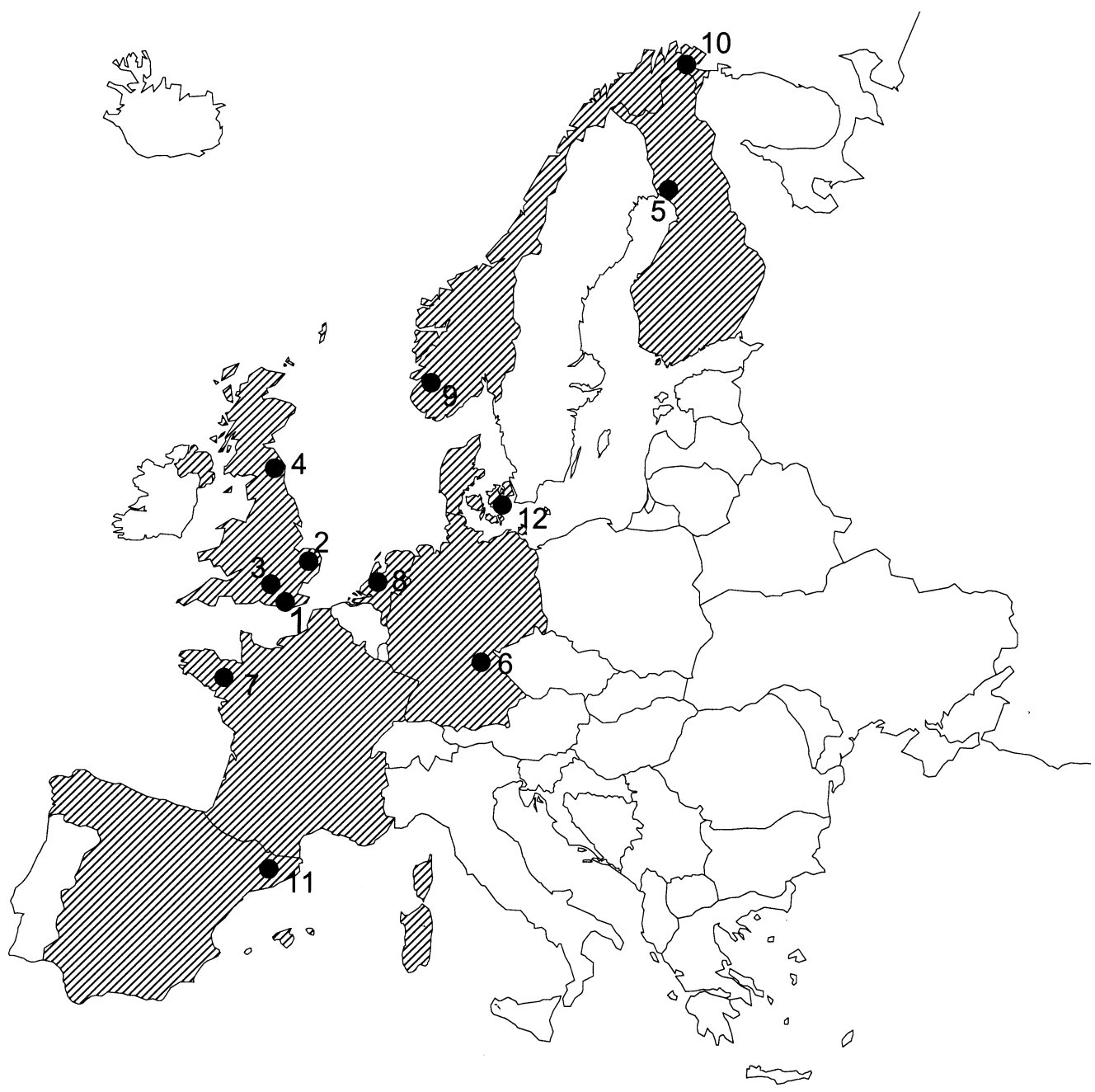

Fig. 3. Distribution of the European study sites used to test and develop the INCA model. The site labels correspond to the numbers listed in Table 1. 
Table 4. A summary of the water chemistry data used in the INCA project

\begin{tabular}{|c|c|c|c|}
\hline Sites & Determinands measured & $\begin{array}{l}\text { Period of } \\
\text { collection }\end{array}$ & Frequency \\
\hline \multicolumn{4}{|l|}{ UK } \\
\hline Leith Hill & $\mathrm{NO}_{3}, \mathrm{NH}_{4}$ & $1998-$ & weekly \\
\hline Ant & $\mathrm{NO}_{2}$ TON & $1971-$ & weekly \\
\hline Kennet & $\mathrm{NO}_{3,} \mathrm{NH}_{4,} \mathrm{SRP}, \mathrm{TP} \mathrm{NO}_{2,}, \mathrm{TON}$ & $1997-1990$ & weekly monthly \\
\hline Tweed & $\mathrm{NO}_{3} \mathrm{NH}_{4}, \mathrm{NO}_{2}, \mathrm{PN}, \mathrm{TP}, \mathrm{TDP}$ & 1994-1996 & \\
\hline 3 core sites & SRP, DOC, major ions, trace & & weekly \\
\hline 3 intensive sites & $\begin{array}{l}\text { elements, } \mathrm{pH} \text {, conductivity, alkalinity, } \\
\text { suspended sediment }\end{array}$ & & $\begin{array}{l}5 \text { week-long } \\
\text { intensive sampling campaigns } \\
\text { (seasonal, daily, diurnal and } \\
\quad \text { tidal cycle sampling) }\end{array}$ \\
\hline $\begin{array}{l}\text { Hundreds of SEPA water } \\
\text { quality sampling sites } \\
\text { across Tweed catchment } \\
\text { (river and effluent sites) }\end{array}$ & $\begin{array}{l}\text { Variable, typically } \mathrm{NO}_{3} \text {, suspended } \\
\text { sediment, orthophosphate, ammonia. }\end{array}$ & 1986-1999 & typically monthly \\
\hline \multicolumn{4}{|l|}{ FINLAND } \\
\hline \multicolumn{4}{|l|}{ River Simojoki } \\
\hline 1 site,outlet 64.01 & $\mathrm{NH}_{4}-\mathrm{N}, \mathrm{NO}_{3}-\mathrm{N}$, tot-N, $\mathrm{PO}_{4}-\mathrm{P}$, tot-P & $\begin{array}{l}1966-1981 \\
1982-\end{array}$ & $\begin{array}{l}2-4 \mathrm{yr}^{-1} \\
8-16 \mathrm{yr}^{-1}\end{array}$ \\
\hline 12 other sites & $\mathrm{NH}_{4}-\mathrm{N}, \mathrm{NO}_{3}-\mathrm{N}$, tot-N, $\mathrm{PO}_{4}-\mathrm{P}$, tot-P & $1966-2000$ & $2-30 \mathrm{yr}^{-1}$ \\
\hline \multicolumn{4}{|l|}{ Germany } \\
\hline $\begin{array}{l}\text { Lehstenbach } \\
2 \text { sites }\end{array}$ & $\begin{array}{l}\mathrm{pH}, \mathrm{Na}, \mathrm{K}, \mathrm{Ca}, \mathrm{Mg}, \mathrm{NH}_{4}, \mathrm{Cl}, \mathrm{NO}_{3} \\
\mathrm{SO}_{4}, \mathrm{Fe}, \mathrm{Al}, \mathrm{PO}_{4}, \mathrm{DOC}, \mathrm{TN}\end{array}$ & 1993-1999 & biweekly \\
\hline $\begin{array}{l}\text { Steinkreuz } \\
2 \text { sites }\end{array}$ & $\begin{array}{l}\mathrm{pH}, \mathrm{Na}, \mathrm{K}, \mathrm{Ca}, \mathrm{Mg}, \mathrm{NH}_{4} \mathrm{Cl}, \mathrm{NO}_{3}, \mathrm{SO}_{4} \\
\mathrm{Fe}, \mathrm{Al}, \mathrm{PO}_{4}, \mathrm{DOC}, \mathrm{TN}\end{array}$ & 1995-1999 & biweekly \\
\hline \multicolumn{4}{|l|}{ FRANCE } \\
\hline Kerbernez: 5 catchments & $\mathrm{NO}_{3}$ & $1991-$ & fortnightly \\
\hline Tremargat: 2 catchments & $\mathrm{NO}_{3}\left(\mathrm{Cl}, \mathrm{SO}_{4}, \mathrm{Ca}, \mathrm{Mg}, \mathrm{K}, \mathrm{Na}, \mathrm{NH}_{4}, \mathrm{PO}_{4}\right)$ & 1998-present & fortnightly \\
\hline Coet Dan : 2 catchments & & 1992-(1993-) & fortnightly \\
\hline $\begin{array}{l}\text { Yar: } 1 \text { main } \\
(+7 \text { subcatchments })\end{array}$ & $\mathrm{NO}_{3}$, Total P & 1987-(1997-) & monthly \\
\hline \multicolumn{4}{|l|}{ NETHERLANDS } \\
\hline $\begin{array}{l}\text { Veluwe Infiltration Area } \\
5 \text { sites }\end{array}$ & $\begin{array}{l}\mathrm{NO}_{3}, \mathrm{NO}_{2}, \mathrm{NH}_{4}, \mathrm{DON}(\mathrm{pH}, \mathrm{EC}, \mathrm{K}, \mathrm{Na} \\
\mathrm{Ca}, \mathrm{Mg}, \mathrm{Fe}, \mathrm{Mn}, \mathrm{Al}, \mathrm{Si}, \mathrm{Cl} \text {, ortho-P, } \mathrm{SO}_{4}, \\
\text { DOC, DOP) }\end{array}$ & Oct.' 88 -present & fortnightly \\
\hline \multicolumn{4}{|l|}{ NORWAY } \\
\hline $\begin{array}{l}\text { RIVER BJERkreim: } \\
21 \text { sites }\end{array}$ & $\begin{array}{l}\mathrm{pH} \text {, cond, } \mathrm{Ca}, \mathrm{Mg}, \mathrm{Na}, \mathrm{K}, \mathrm{Cl}, \mathrm{SO}_{4}, \mathrm{NO}_{3}, \\
\text { TN, Alk, TOC, R-Al, IL-Al, TP, } \mathrm{SiO}_{2}\end{array}$ & $1993-2000$ & $\begin{array}{l}\text { weekly/fortnightly/monthly } \\
\text { samples }\end{array}$ \\
\hline Dalelv Brook & $\mathrm{pH}$, cond, $\mathrm{Ca}, \mathrm{Mg}, \mathrm{Na}, \mathrm{K}, \mathrm{Cl}, \mathrm{SO}_{4}, \mathrm{NO}_{3}$, & $1988-1993$ & $1-4$ times/yr \\
\hline 3 lake sites 1 river site & TN, Alk, TOC, R-Al, IL-Al, $\mathrm{NH}_{4}$ & $1988-2000$ & $\begin{array}{l}\left(\mathrm{NH}_{4} \text { data for } 1992 \text { only) }\right. \\
\text { weekly samples }\end{array}$ \\
\hline \multicolumn{4}{|l|}{ SPAIN } \\
\hline 2 sites & $\begin{array}{l}\mathrm{pH}, \mathrm{Na}, \mathrm{K}, \mathrm{Ca}, \mathrm{Mg}, \mathrm{NH}_{4}, \mathrm{Cl}, \mathrm{NO}_{3}, \mathrm{SO}_{4}, \\
\mathrm{Fe}, \mathrm{Al}, \mathrm{PO}_{4}, \mathrm{DOC}, \mathrm{TN}\end{array}$ & 1993-1999 & biweekly \\
\hline \multicolumn{4}{|l|}{ DENMARK } \\
\hline Vestskoven & $\begin{array}{l}\mathrm{NO}_{3}, \mathrm{NH}_{4} \text {, total } \mathrm{P} \mathrm{NO}_{3}, \mathrm{NH}_{4}, \mathrm{pH}, \mathrm{EC}, \mathrm{Cl} \text {, } \\
\mathrm{SO}_{4} \mathrm{NO}_{3}, \mathrm{NH}_{4}, \mathrm{pH}, \mathrm{EC}, \mathrm{Cl}, \mathrm{SO}_{4} \mathrm{Na}, \mathrm{Ca} \text {, } \\
\mathrm{Mg}, \mathrm{K}, \mathrm{Al} \text {, total P, DOC }\end{array}$ & $\begin{array}{l}\text { Dec.'98-May'99 } \\
\text { Dec.99-June '00 } \\
\text { July'00-present }\end{array}$ & monthly \\
\hline
\end{tabular}


- France, UK and Spain. Applications using data from catchments in France, UK and Spain will focus on the impacts of arable and livestock farming on $\mathrm{N}$ pollution in river systems. Six catchments in France, one in Spain and four in the UK will be modelled. The French catchments are located in Brittany, where the land use is divided equally among maize, cereal and pasture (Ruiz et al., 2002a, b). These catchments range in size from 0.35 to $59 \mathrm{~km}^{2}$. In contrast, the UK catchments vary both in location and size. Leith Hill is a small ( 0.93 $\mathrm{km}^{2}$ ) catchment in southern England dominated by coniferous forest and heathland, thought to be sensitive to $\mathrm{N}$ deposition (Whitehead et al., 2002). The Ant in eastern England and the Kennet in southern England are both larger at 50 and $1033 \mathrm{~km}^{2}$, respectively, and both are dominated by intensive wheat and barley production. In contrast, the River Tweed catchment includes a mixture of arable and pastoral agriculture (Wade et al., 2002; Jarvie et al., 2002). In addition, a plot study sited on the riparian zone of the BedfordOuse, England has been designed to provide estimates of $\mathrm{N}_{2} \mathrm{O}$ emissions from nitrification and denitrification, with the aim of producing an equation for inclusion in INCA to simulate the release of $\mathrm{N}_{2} \mathrm{O}$ from the nitrification and denitrification processes (Machefert et al., 2002). The Fuirosus catchment in Spain represents the most southerly INCA study site in Europe, with a Mediterranean climate (Butturini and Sabater, 2002; Butturini et al., 2002). The catchment covers an area of $13 \mathrm{~km}^{2}$, and the land -use comprises a mixture of pine and oak forest and limited agricultural production, which occupies only $5 \%$ of the catchment area. The application of INCA to the Fuirosus system will test the model's ability to simulate a Mediterranean stream hydrograph, which is characterised by a long dry summer period, snowmelt in spring and floods in autumn.

Substantial historical, hydrological and hydrochemical data sets are available for all these sites, with many sets collected as part of long-term or major European initiatives such as CLIMEX or NITREX (Tietema and Beier, 1995). These provide important resources that can be used to analyse the spatial and temporal variations in the $\mathrm{N}$ fluxes, and to calibrate and test the INCA model. In addition to these data sets, many new data have been collected to aid the description of system functioning and data describing the land use types and management practices have been collated to facilitate INCA applications to simulate the future response in river $\mathrm{N}$ concentrations and loads (e.g. Rankinen et al., 2002).
Given that an aim of the project is to investigate whether a single model can be developed to cover all $\mathrm{N}$ issues throughout Europe at all spatial and temporal scales, then during the initial phases of the project, the original INCA model structure was changed to make the model more generally applicable to all the study sites (Wade et al., 2002). The newly developed INCA represents a consensus regarding a theory of $\mathrm{N}$ transport and retention in catchments by scientists involved in laboratory work, fieldwork and modelling in a range of systems, written with explicit assumptions and in mathematical terms. Thus, the model, and the theory it represents, can be used as a basis for subsequent testing by other interested parties, ideally leading to an improved understanding of catchment $\mathrm{N}$ dynamics either through the model's acceptance or rejection.

\section{SCENARIOS. INCA A TOOL FOR CATCHMENT MANAGEMENT}

In recognition of the adverse impacts of $\mathrm{N}$ and the need for integrated management, the EU has introduced a series of Directives aimed at reducing $\mathrm{N}$ pollution in aquatic systems. The most recent include the Water Framework Directive (2000/60), amendments to the Large Combustion Plant Directive (88/609/EEC) and the proposal for a National Emission Ceilings Directive. The latter two parallel the UN/ ECE Gothenberg Protocol that includes annual emission ceilings for 2010 for nitrogen oxides and ammonia. There are also older Directives aimed at reducing the impact of $\mathrm{N}$, these include the Nitrate, Habitat and Wastewater Treatment Directives, the latter focused mainly on phosphorus pollution. Since many EU policies are aimed to control N in river systems, there is a need to understand the combined result of their implementation.

The deposition scenarios used in the project will be based on the expected impacts of the Directives controlling emissions, and the land-use change scenarios will be based on 'standard' agricultural practice changes (as defined by CAP or national agricultural pollution remediation policy) and more prospective remediation techniques, for example, data collected in the Lehstenbach catchment in Germany during a period of clear cut and replanting will provide an excellent opportunity with which to test the INCA model performance in simulating the effects of timber harvesting on catchment $\mathrm{N}$ dynamics. By combining the outputs of the INCA and TNT (Beaujouan et al., 2001) models, with remotely sensed crop classification data, Digital Terrain Model data and a farmland classification system, it may be possible to classify land-use types according to N leaching risk. In addition, data from Global Circulation Models developed at the UK Hadley Centre for Climatic Change 
will be used to drive the climate scenarios. Thus, the impacts of the changes in the $\mathrm{N}$ sources on the study sites will be determined singly, and set against the background of potential climatic change, in the latter project stages.

\section{PARAMETER AND STRUCTURAL UNCERTAINTY}

Difficulties arise when trying to simulate the transfer of water and pollutant loads through catchment systems (Beven, 1993). In particular, problems relate to spatial and temporal scaling as the structure and parameters of current models usually cannot represent adequately the spatial and temporal variability observed in water chemistry data. Moreover, process-based, dynamic water quality models are often over-parameterised resulting in non-unique parameter values and equifinality in model representation (Oreskes et al., 1994). The INCA project aims to address the problem of parameter uncertainty by comparing the parameter sets obtained from the model applications to find which parameters are most important in controlling the model behaviour and which are redundant. As such, it may be possible to determine the key features of the model needed to simulate $\mathrm{N}$ dynamics throughout Europe.

The fully distributed hydrological and soil-plant model (TNT) will be used to assess the $\mathrm{N}$ dynamics within small French catchments. If both INCA and TNT can reproduce the $\mathrm{N}$ dynamics observed then neither structure will be rejected, and both models will be run in a predictive mode to estimate the future changes in the streamwater $\mathrm{N}$ concentrations according to the prescribed scenarios. The range of outcomes should reflect the variations in the predicted water chemistry response that can be attributed to structural uncertainty. Thus, this analysis may provide information regarding the level of process representation required to model water chemistry across a range of spatial scales.

\section{LINKS TO ECONOMICS: A TOOL FOR POLICY DECISIONS}

There are two general economic approaches to controlling the $\mathrm{N}$ levels in river systems. In the first approach, the optimal streamwater $\mathrm{N}$ concentration is defined as the concentration at which the marginal cost of $\mathrm{N}$ reduction is equal to its marginal benefit. In the absence of information on the costs and benefits, the second approach is to set an acceptable target $\mathrm{N}$ level. In this second case, the benefit of reducing $\mathrm{N}$ in the river system is assumed, thus side-stepping the difficult issue of evaluating the benefit of a given reduction in $\mathrm{N}$ concentrations. The objective of the second approach is to minimise the cost of achieving the target level of $\mathrm{N}$. The economic component of the INCA project assumes a target reduction, which can be specified in the terms of either streamwater $\mathrm{N}$ concentration $\left(\mathrm{mg} \mathrm{N}^{-1}\right)$, $\mathrm{N}$ leaching $\left(\mathrm{kg} \mathrm{N} \mathrm{ha}^{-1} \mathrm{yr}^{-1}\right)$ or $\mathrm{N}$ fertiliser application $\left(\mathrm{kg} \mathrm{N} \mathrm{ha}^{-1} \mathrm{yr}^{-1}\right)$.

The approach adopted for modelling the impact of controls directed at $\mathrm{N}$, on agriculture, is based on linear programming, a well-established tool in agricultural economics. The essence of the approach is the maximisation of the sum of gross margins of agricultural activities, subject to a set of constraints. Activities include tillage and livestock rearing and the constraints include:

- Resource constraints, such as limits on land and labour;

- crop rotations, limiting the frequency with which particular crops can be grown for crop husbandry.

A common problem with the linear programming approach is that it often fails to represent the true agricultural diversity observed in terms of crop types and livestock enterprises. This prevents successful model simulation and, therefore, limits the model's utility for predicting the effect of policy on agriculture. To optimise the simulation to the observed land distribution, a large number of constraints, which may not be justified empirically, must be included (Howitt, 1995). In addition, these constraints that are set during model calibration to a base year, may not be appropriate for model applications that aim to determine the impacts of policies different to those in effect during the base year: the model's flexibility is compromised. To address this problem, a new approach was developed called Positive Mathematical Programming (PMP), and the approach was adapted to minimise the information required during calibration (Paris, 1988). Due to the lack of information available to implement the Howitt's version of PMP, Paris' approach was chosen as a basis for the new economic model developed within the INCA study. This approach introduces a non-linear term into the model's objective function, which enables exact calibration. Once calibrated, the effect of the introduction of a tax on fertiliser, for example, is achieved by modifying the objective function. A quantitative limit on the amount of $\mathrm{N}$ applied can be incorporated as a model constraint.

In the new economic model, a single representative farmer for the catchment is assumed and by examining the resource re-allocation amongst farm enterprises, inferences on the welfare distribution between different farmers resulting from policy, can be made. Thus, estimates of changes in agricultural income and employment can be obtained. In addition, the economic model will also provide estimates of how $\mathrm{N}$ fertiliser applications will change in response to fertiliser taxation, and the changes in land-use type and 
livestock numbers within a catchment. This information will, in turn, be input into INCA to determine the response in the streamwater $\mathrm{NO}_{3}$ concentrations. Thus, the combined output from the INCA and the economic model will be used to investigate the degree to which policies achieve their stated aims and the likely costs of these policies within agriculture.

\section{LINKS TO OTHER STUDIES}

The recent emphasis on integrated catchment planning and unifying EU directives has led to considerable research interest in the study of large river systems. In particular, the pursuit of models and modelling frameworks capable of predicting water quality across ranges of spatial and temporal scales has provided key motivation. Recent UK and European initiatives include the Land Ocean Interaction Study (LOIS), the European Land Ocean Interaction Study (ELOISE) and the Large Scale Processes in Ecology and Hydrology (LSP) project (Neal et al., 1997; Langan et al., 1997). INCA will add to these projects by addressing the issues of the integration of catchment heterogeneity, process understanding and water quality measurements within water quality models. The INCA model will also provide estimates of $\mathrm{N}$ fluxes to estuarine and marine ecosystems, thereby providing direct input to ELOISE. In adopting the PMP approach, the economics component applies the current agricultural modelling method implemented in the European project 'Tools for Evaluating EU Agricultural Policies at Different Decision Levels - (EUROTOOLS, 2000).

\section{SPECIAL VOLUME}

This Special Volume reports the findings of the project to date together with recent associated work and discusses the key findings in terms of river system functioning, model development and catchment management set within national and broader European and global contexts. Given the project is only 18 months old, the findings focus on objectives 1 to 6 and 9. Objectives 7 and 8 will be addressed in the latter stages of the project, and reported in future publications.

\section{Conclusions}

The INCA project provides a key opportunity to collect new data and develop and test the INCA model in a broad range of European environments, thereby adding to the knowledge base regarding $\mathrm{N}$ processes in river systems. It is envisaged that the INCA applications will yield important new information on modelling $\mathrm{N}$ retention and transport within catchments and, in particular will investigate whether it is possible to create a single model capable of application to a range of spatial and temporal scales and $\mathrm{N}$ issues. The initial phase of the work is now complete and the promising results are reported in papers included in this Special Volume.

\section{Acknowledgements}

This research is supported by the European Commission (Project EVK1-1999-00011), and the results are derived from collaborations among all the project partners, who are listed on the project website: http://www.reading.ac.uk/ INCA. The authors would like to thank Heather Browning for help with the diagrams.

\section{References}

Abbot, M.B., Bathurst, J.C., Cunge, J.A., O’Connell, P.E. and Rasmussen, J., 1986. An introduction to the European Hydrological System - Système Hydrologique Européen 'SHE' 1: history and philosophy of a physically-based, distributed modelling system. J. Hydrol., 87, 45-59.

Addiscott, T.M. and Whitmore, A.P., 1987. Computer simulation of changes in soil mineral nitrogen and crop nitrogen during autumn, winter and spring. J. Agri. Sci., 109, 149-188.

Beaujouan, V., Durand, P. and Ruiz, L., 2001. Modelling the effect of the spatial distribution of agricultural practices on nitrogen fluxes in rural catchments. Ecol. Model., 137, 91-103.

Beven, K., 1993. Prophecy, reality and uncertainty in distributed hydrological modelling. Adv. Water Resour., 16, 41-51.

Butturini, A. and Sabater, F., 2002. Nitrogen concentrations in a small Mediterranean stream: I. Nitrate. II. Ammonium. Hydrol. Earth Syst. Sci., 6, 539-550.

Butturini, A., Bernal, S., Sabater, S. and Sabater, F., 2002. The influence of riparian-hyporheic zone on the hydrological responses in an intermittent stream. Hydrol. Earth Syst. Sci., 6, 515-525.

Cooper, D.M., Ragab, R. and Whitehead, P.G., 1993. IHDMTRANS a nitrate model for agricultural systems, IH report to MAFF. Institute of Hydrology, Wallingford, UK.

COM (99) 125., 1999. Proposal for a Directive setting national emission ceilings for certain atmospheric pollutants and for a Daughter Directive relating to ozone in ambient air. Council of Ministers, European Commission.

Cosby, B.J., Hornberger, G.M., Galloway, J.N. and Wright, R.F., 1985a. Time scales of acidification: a quantitative model for estimating freshwater acidification. Environ. Sci. Technol., 19, 1144-1149.

Cosby, B.J., Wright. R.F., Hornberger, G.M. and Galloway, J.N., 1985b. Modelling the effects of acid deposition: Assessment of a lumped parameter model of soil water and streamwater chemistry. Water Resour. Res., 21, 51-63.

Cosby, B.J., Ferrier, R.C., Jenkins, A., Emmett, B.A., Wright, R.F. and Tietema, A., 1997. Modelling the ecosystem effects of nitrogen deposition: Model of Ecosystem Retention and Loss of Inorganic Nitrogen (MERLIN). Hydrol. Earth Syst. Sci., 1, $137-158$.

Emmett, B.A., Brittain, S.A., Hughes, S. and Kennedy, V., 1995. Nitrogen additions $\left(\mathrm{NaNO}_{3}\right.$ and $\left.\mathrm{NH}_{4} \mathrm{NO}_{3}\right)$ at Aber forest, Wales: II Response of trees and soil nitrogen transformations. Forest Ecol. Manage., 7, 61-73.

EPA, 1999. A summary of US effluent trading and offset projects, US Environmental Protection Agency, Office of Water, USA. 
EUROTOOLS, 2000. Tools for evaluating EU agricultural policy at different decision levels, Final Report submitted under the Commission of the European Communities (Agriculture and Fisheries - FAIR) specific RTD programme, CT97-3403.

Hansen, J., 2000. Statistics in Focus. Environment and Energy, Theme 8 - 16/2000. Eurostat/F3, L-2920 Luxembourg.

Hornung, M., Bull, K., Cresser, M.S., Hall, J., Langan, S. J., Loveland, P. and Wilson, M.J., 1994. The sensitivity of surface waters of Great Britain to acidification predicted from catchment characteristics. Environ. Pollut., 87, 207-214.

Hornung, M., Cresser, M.S., Bull, K., Langan, S.J., Loveland, P.J., Wilson, M.J., Hall, J. and Smith, C., 1995. An empirical map of critical loads of acidity for soils in Great Britain. Environ. Pollut., 90, 301-310.

Howitt, R.E., 1995. Positive mathematical programming, Amer. J. Agr. Econ., 77, 329--342.

Jarvie, H.P., Wade, A.J., Butterfield, D., Whitehead, P.G., Tindall, C.I., Virtue, W.A., Dryburgh, W. and McGraw, A., 2002. Modelling nitrogen dynamics and distributions in the River Tweed, Scotland: an application of the INCA model. Hydrol. Earth Syst. Sci., 6, 433-453.

Jenkins, A., Ferrier, R.C. and Cosby, B.J., 1996. A Dynamic Model for Assessing the Impacts of Coupled Sulphur and Nitrogen Deposition Scenarios on Surface Water Acidification. J. Hydrol., 197, 111-127.

Jenkins, A., Renshaw, M., Helliwell, R.C., Sefton, C., Ferrier, R. and Singewood, P., 1997. Modelling surface water acidification in the UK. Institute of Hydrology Report No. 131, Wallingford, UK. 54 pp.

Johnes, P.J., 1996. Evaluation and management of the impact of land use change on the nitrogen and phosphorus load delivered to surface waters: the export coefficient modelling approach, $J$. Hydrol., 183, 323-349.

Johnson, S.L., Adams, R.M. and Perry, G.M., 1991. The on-farm costs of reducing groundwater pollution, Amer. J. Agr. Econ., 73, 1063-1073.

Kaste, O. and Skjelkvale, B., 2002. Nitrogen dynamics in runoff from two small heathland catchments representing opposite extremes with respect to climate and $\mathrm{N}$ deposition in Norway. Hydrol. Earth Syst. Sci., 6, 351-362.

Langan, S.J., Wade, A.J., Smart, R., Edwards, A.C., Soulsby, C., Billet, M F., Jarvie, H.P., Cresser, M.S., Owen, R. and Ferrier, R.C., 1997. The prediction and management of water quality in a relatively unpolluted major Scottish catchment: current issues and experimental approaches. Sci. Total Envir., 194/195, 419-435.

Langusch, J-J. and Matzner, E., 2002a. N fluxes in two nitrogen saturated forested watersheds in germany: Dynamics and modeling with INCA. Hydrol. Earth Syst. Sci., 6, 383-394.

Langusch, J-J. and Matzner, E., 2002b. Long-term modelling of nitrogen turnover and critical loads in a forested catchment using the INCA model. Hydrol. Earth Syst. Sci., 6, 395-402.

Lunn, R.J., 1995. A nitrogen modelling system for large river basins. Unpublished PhD Thesis, University of Newcastle, Newcastle, UK.

Machefert, S.E., Dise, N.B., Goulding, K.W.T. and Whitehead, P.G., 2002. Nitrous oxide emission from a range of land-uses across Europe. Hydrol. Earth Syst. Sci., 6, 325-337.

Neal, C., House, W.A., Leeks, G.J.L. and Marker, A.H., 1997. Conclusions to the special volume of Science of the Total Environment concerning UK fluxes to the North Sea, Land Ocean Interaction Study (LOIS): river basins research, the first two years. Sci. Total Envir., 194/195, 467-478.

Neal, C., House, W.A., Whitton, B.A. and Leeks, G.J.L., 1998. Conclusions to special issue: water quality and biology of UK rivers entering the North Sea: The Land Ocean Interaction Study (LOIS) and associated work. Sci. Total Envir., 210/211, 585594.
Oreskes, N., Shrade-Frechette, K. and Belitz, K., 1994. Verification, Validation and Confirmation of Numerical Models in the Earth Sciences. Science, 263, 641-646.

O'Shea, L.C.M., 2001. An economic approach to reducing water pollution: point and diffuse sources. Sci. Total Envir., 282/283, 49-63.

Paris, Q., 1988. PQP, PMP Parametric programming and comparative statistics. Notes for AE 253. Department of Agricultural Economics, University of California, Davis, USA.

Postek, K.M., Driscoll, C.T., Aber, J.D. and Santore, R.C., 1995. Application of PNet-CN/CHESS to a Spruce stand in Solling, Germany. Ecol. Model., 83, 163--172.

Raat, R.J., Draaijers, G.P.J., Schaap, M.G., Tietema, A. and Verstraten, J.M., 2002. Spatial variability of throughfall water and chemistry and forest floor water content in a Douglas fir forest stand. Hydrol. Earth Syst. Sci., 6, 363-374.

Rankinen, K., Lepisto, A. and Granlund, K., 2002. INCA hydrological application with varying spatial resolution and nitrogen dynamics in a northern river basin in Finland. Hydrol. Earth Syst. Sci., 6, 339-350.

Ruiz, L., Abiven, S., Durand, P., Martin, C., Vertes, F. and Beaujouan, V., 2002a. Effect of nitrate concentration in stream water of agricultural practices in small catchments in Brittany. I - Annual nitrogen budgets. Hydrol. Earth Syst. Sci., 6, 497505.

Ruiz, L., Abiven, S., Martin, C., Durand, P., Vertes, F., Beaujouan, V. and Molenat, J., 2002b. Effect of nitrate concentration in stream water of agricultural practices in small catchments in Brittany. II - Temporal variations and mixing processes. Hydrol. Earth Syst. Sci., 6, 507-513.

Skeffington, R. and Wilson, E.J., 1988. Excess nitrogen deposition: issues for consideration. Environ. Pollut., 54, 159-184.

Stanners, D and Bordeau, P., (Eds.), 1995. Europe's environment: The Dobris Assessment. Prepared by the European Environment Agency Task Force (European Commission, DG XI and Phare) in co-operation with United Nations Economic Commission for Europe Copenhagen, European Environment Agency, 676pp.

Tietema, A. and Beier, C., 1995. Correlative evaluation of nitrogen cycling in the forest ecosystem of the EEC projects NITREX and EXMAN., Forest Ecol. Manage., 71, 143-151.

Thornley, J.H.M. and Cannell, M.G.R., 1992. Nitrogen relations in a forest plantation - soil organic matter ecosystem model. Ann. Bot., 70, 137-151.

Van de Velde, R.J. Faber, W., van Katwijk, V., Scholten, H.J., Thewessen, Th., Verspuy, M. and Zevenbergen, M., 1994. The Preparation of a European Land Use Database. RIVM report no 712401001, Bilthoven., The Netherlands.

Vatn, A., Bakken, L.R., Lundeby, H., Romstad, E., Rorstad, P.K., Vold, A. and Botterweg, P. 1997. Regulating nonpoint-source pollution from agriculture: an integrated modelling analysis, Eur. Rev. Agric. Econ., 24, 207-229.

Wade, A.J., Soulsby, C., Langan, S.J., Whitehead, P.G., Edwards, A.C., Butterfield, D., Smart, R.P., Cook, Y. and Owen, R.P., 2001. Modelling instream nitrogen variability in the Dee catchment, NE Scotland. Sci. Total Environ., 265, 229-252.

Wade, A J., Durand, P., Beaujouan, V., Wessel, W.W., Raat, K.J., Whitehead, P.G., Butterfield, D., Rankinen, K. and Lepisto, A., 2002. Towards a generic nitrogen model of European ecosystems: INCA, new model structure and equations. Hydrol. Earth Syst. Sci., 6, 559-582.

Weaver, R.D., Harper, J.K. and Gillmeister, W.J., 1996. Efficacy of Standards vs. incentives for managing the environmental impacts of agriculture, J. Environ. Manage., 46, 173-188.

Wheater, H.S. and Beck, M.B., 1995. Modelling Upland Stream Water Quality: Process Identification and Prediction Uncertainty. In: Solute Modelling in Catchment Systems, S.T. Trudgill (Ed.), Wiley, Chichester, UK. 305-324. 
Whitehead, P.G. and Williams, R.J., 1984. Modelling algal behaviour in the River Thames. Water. Res., 18, 945-953.

Whitehead, P.G., Williams, R.J. and Lewis, D., 1997. Quality simulation along river systems (QUASAR): model theory and development. Sci. Total Envir. 194/195, 447-456.

Whitehead, P.G., Wilson, E.J. and Butterfield, D., 1998a. A semidistributed Nitrogen Model for Multiple Source Assessments in Catchments (INCA): Part 1 - Model Structure and Process Equations. Sci. Total Envir., 210/211, 547-558.

Whitehead, P.G., Wilson, E. J., Butterfield, D. and Seed, K., 1998b. A semi-Distributed Integrated Flow and Nitrogen Model for Multiple Source Assessment in Catchments (INCA): Part II Application to large River Basins in South Wales and Eastern England. Sci. Total Envir., 210/211, 559-583.
Whitehead, P.G., Lapworth, D.J., Skeffington, R.A., and Wade, A.J., 2002. Excess nitrogen leaching and $\mathrm{C} / \mathrm{N}$ decline in the Tillingbourne catchment, southern England: INCA process modelling for current and historic time series. Hydrol. Earth Syst. Sci., 6, 455-466.

Wilkinson, W.B., Leeks, G.J.L., Morris, A. and Walling, D.E., 1997. Rivers and coastal research in the Land Ocean Interaction Study. Sci. Total Environ., 194/195, 5-14.

Wilson, E.J. and Emmett, B.A., 1997. Factors influencing nitrogen saturation in forest ecosystems: advances in our understanding since the mid 1980's. In: The impact of Nitrogen Deposition on Natural and Semi-Natural Ecosystems, S.J. Langan and M.J. Wilson (Eds.). Chapman and Hall, London. 
